\title{
The contribution of deadwood to soil carbon dynamics in contrasting temperate forest ecosystems
}

\author{
V. L. Shannon ${ }^{1}$ - E. I. Vanguelova ${ }^{2} \cdot$ J. I. L. Morison ${ }^{2} \cdot$ L. J. Shaw ${ }^{1} \cdot$ J. M. Clark ${ }^{1}$
}

Received: 17 June 2021 / Revised: 30 November 2021 / Accepted: 6 December 2021 / Published online: 16 December 2021

(c) The Author(s) 2021

\begin{abstract}
Deadwood forms a significant carbon pool in forest systems and is a potential source of dissolved organic carbon (DOC) input to soil, yet little is known about how deadwood effects forest soil carbon cycling. Deadwood DOC inputs to soil may be retained through sorption or may prime microbial decomposition of existing organic matter to produce additional DOC. To determine impacts of deadwood on soil C cycling, we analysed surface soil from beneath deadwood or leaf litter only, along chronosequences of stands of lowland oak and upland Sitka spruce. The concentration and quality (by optical indices) of water-extracted soil DOC (water-extractable organic carbon; WEOC), in situ decomposition 'tea bag index' (TBI) parameters and enzymatic potential assays ( $\beta$-D-cellubiosidase, $\beta$-glucosidase, $\beta$-xylosidase, leucine aminopeptidase, phosphatase, phenol oxidase) were determined. Presence of deadwood significantly $(p<0.05)$ increased WEOC concentration $(\sim 1.5$ to $\sim 1.75$ times) in the mineral oak soil but had no effect on WEOC in spruce soils, potentially because spruce deadwood DOC inputs were masked by a high background of WEOC (1168 $\mathrm{mg} \mathrm{kg}^{-1}$ soil) and/or were not retained through mineral sorption in the highly organic ( 90\% SOM) soil. TBI and enzyme evidence suggested that deadwood-derived DOC did not impact existing forest carbon pools via microbial priming, possibly due to the more humified/aromatic quality of DOC produced (humification index of 0.75 and 0.65 for deadwood and leaf litter WEOC, respectively). Forest carbon budgets, particularly those for mineral soils, may underestimate the quantity of DOC if derived from soil monitoring that does not include a deadwood component.
\end{abstract}

Keywords Coarse woody debris $\cdot$ Dissolved organic carbon $\cdot$ Forest soils $\cdot$ Microbial priming

\section{Introduction}

Forests are acknowledged as large and important carbon (C) sinks, storing carbon in soils and both living and dead biomass. Globally, forests are estimated to hold $861 \pm 66 \mathrm{Pg} \mathrm{C}$, of which $119 \pm 6 \mathrm{Pg}$ are accounted for by temperate forest ecosystems (Pan et al. 2011). The amount of carbon stored in forest soils and biomass varies with forest type. Pan et al. (2011) state that tropical forests hold 56\% of carbon

Communicated by Claus Bässler.

V. L. Shannon

v.1.shannon@pgr.reading.ac.uk

1 Soil Research Centre, Department of Geography and Environmental Science, University of Reading, Whiteknights, PO box 227, Reading RG6 6AB, UK

2 Forest Research, Alice Holt Lodge, Surrey GU10 4LH Farnham, UK in biomass with only $32 \%$ in the soil whereas boreal and temperate forests may hold $20 \%$ and $37 \%$ in biomass and $60 \%$ and $49 \%$ in soil, respectively. The remaining carbon is held within litter and deadwood and Pan et al. (2011) estimated that $8 \%(73 \pm 6 \mathrm{Pg}$ ) of the world's forest $\mathrm{C}$ is held in deadwood. In the UK, forests store up to $1 \mathrm{Pg} \mathrm{C}$ (Morison et al. 2012), of which 74\% is held within the soils down to $1 \mathrm{~m}$ depth (Vanguelova et al. 2013). The remaining 26\% C is split between tree biomass (22\%) and litter and deadwood (4\%) (Morison et al. 2012). The stock of $\mathrm{C}$ in deadwood alone in the UK represents $3.5 \%$ of the total forest $\mathrm{C}$ storage, with almost twice the amount per unit area in conifer $\left(2.36 \mathrm{t} \mathrm{C} \mathrm{ha}^{-1}\right)$ when compared to broadleaved forests $\left(1.24 \mathrm{t} \mathrm{Cha}^{-1}\right)$ (Vanguelova et al. in-press). Deadwood may be present in the form of standing or lying dead trees or as stumps, with standing and lying deadwood categorised into decay classes for inventory purposes (Hunter 1990). For example, for lying deadwood, the decay classes range from 1 (least decomposed; intact bark, texture and structure) 
to 5 (most decomposed; bark absent, powdery texture and structure collapsed) (Hunter 1990). Currently about 50\% of the deadwood in the UK is in a less degraded state, at less than $10 \%$ decay or decay class 2 , and the rest in different decay classes (Vanguelova et al. in-press).

Initiation of the decomposition of wood is thought to be primarily carried out by fungi (Schwarze et al. 2000) and occurs slowly, as the lignin content of wood provides a physical barrier to the enzymatic decomposition of nonlignin macromolecules, and, as such, it can take decades before a tree is fully decomposed (Russell et al. 2014). Research has shown that most conifers are slower to decay than broadleaved species (Weedon et al., 2009; Shorohova and Kapitsa 2014; Herrmann et al. 2015), partially due to the greater amounts of lignin, waxes, lipids and resins found in coniferous wood (Li et al. 2007; Lukac and Godbold 2011). Wood decay begins immediately following the death of cells. After the action of lignin peroxidases or polyphenol oxidases (Janusz et al. 2017), the resulting depolymerisation of lignin structures allows easier access for extracellular hydrolytic enzymes that are responsible for the depolymerization of polymers such as cellulose and hemicellulose (Li et al. 2018). These depolymerization reactions produce lower molecular weight compounds with increased solubility and initial bioavailability; deadwood-derived dissolved organic carbon (DOC) may enter underlying soil via leaching (Wambsganss et al. 2017; Piaszczyk et al. 2019b), contributing to the soil DOC pool and undergoing subsequent fates, e.g. microbial metabolism including respiration to, or driving production of, greenhouse gases $\left(\mathrm{CO}_{2}, \mathrm{CH}_{4}, \mathrm{~N}_{2} \mathrm{O}\right)$ or stabilization (Wambsganss et al. 2017) through interaction with soil minerals (Guggenberger and Kaiser 2003), depending on its quality. The flux of DOC released by deadwood (44-53 mg per g material) has been found to be comparable to leaf litter (47-49 mg per g material) and is significantly greater than forest vegetation and the upper soil layers (3-18 mg per g material) (Hollands et al. 2022).

Although we know that deadwood forms a significant pool of $\mathrm{C}$ in forest systems, and previous studies have shown that soil DOC concentrations are elevated in forest systems with deadwood when compared to those without (Spears and Lajtha 2004; Hafner and Groffman 2005; Kahl et al. 2012; Stutz et al. 2019; Minnich et al. 2021; Hollands et al. 2022), it is less clear what effects the presence of deadwood has on forest soil $\mathrm{C}$ cycle processes and how this varies in contrasting forests. It is not clear if the reported elevations in soil DOC concentrations are a result of solely the input and subsequent stabilization of deadwood decomposition derived DOC, or, if inputs of deadwood DOC promote the release of DOC from existing soil organic matter (SOM) (Minnich et al. 2021). On the one hand, deadwood-derived DOC might be stabilized in soil as a result of either: (i) chemical protection from decomposition through association with mineral phases; (ii) physical protection through sequestration within soil structure; or, (iii) biochemical protection through inherent or acquired structural recalcitrance (Six et al. 2002; von Luetzow et al. 2006; Piaszczyk et al. 2019a). On the other hand, deadwood DOC components may prime decomposition of, or release DOC from, existing SOM pools through: (i) stimulation of microbial activity and as such enzymatic activity (Fontaine et al. 2003; Gonzalez-Polo et al. 2013; Beverly and Franklin 2015; Minnich et al. 2021) which in turn primes increased depolymerisation of, and release of DOC from, native soil organic matter; or (ii) abiotic liberation of native dissolved organic compounds from protective associations with minerals (Keiluweit et al. 2015). As previously mentioned, deadwood varies with respect to the stage of wood decomposition, or decay class. Wood decay class is known to influence subsequent rates of deadwood decomposition (Tobin et al. 2007; Olajuyigbe et al. 2011; Stutz et al. 2019). Wood in the late stages of decay hosts a greater primary decomposer microbial biomass (Kueffer et al. 2008; Baldrian et al. 2016). Increased microbial and fungal biomass in and under deadwood (Peršoh and Borken 2017) may lead to larger DOC and $\mathrm{CO}_{2}$ fluxes being produced, and therefore potentially enhance impacts on the soil DOC pool and $\mathrm{C}$ cycling processes. Wood composition will also influence the rates of decay, with wood from conifers ('softwoods') and broadleaves ('hardwoods') decaying at different rates (Herrmann et al. 2015), and likely producing different quality and lability of DOC.

Soil properties, such as soil texture and type, $\mathrm{pH}$ and moisture will affect the amount of organic matter held in soils (Matus 2021) and influence the rate of decomposition processes that may release DOC. Silt and clay content in soils may capture and stabilize organic compounds through sorption (Six et al. 2002; Villada 2013; Matus 2021). Low soil $\mathrm{pH}$ and high moisture content inhibit decomposition rates (Hagemann et al., 2010) which may increase SOM accumulation (Keith et al. 2009). It is possible that the physical presence of large woody debris on the forest floor may create a localised microclimate, through the shading of soils which will affect temperature, or preventing water and litter reaching the soil. In tropical forests, deadwood has been found to buffer soil temperature, preventing diurnal fluctuations (Zalamea et al. 2016). Anoxic conditions can be created through waterlogging of soils and these conditions are known to inhibit decomposition processes (Hagemann et al. 2010). However, little research has been carried out into the creation of microclimates under deadwood in temperate forests (Woodall et al. 2020).

Accordingly, the aim of this study is to confirm whether deadwood produces significant inputs of DOC into underlying soil and to identify the effect this has on $\mathrm{C}$ cycling. Specific objectives of this study are to: (1) identify whether the presence of lying deadwood influences the amounts of DOC 
in underlying soil, comparing common hardwood (oak) and softwood (Sitka spruce) species on their typical soil types in Britain; (2) identify the impact of deadwood on soil carbon processes and cycling; and, (3) characterize the quality of soil DOC in order to help identify its source and potential lability. We use a combination of traditional measurements (e.g. extracellular enzyme potentials as sensitive indicators of change in decomposition processes) and more novel indices, as applied to forest $\mathrm{C}$ studies, to derive decomposition data (the teabag index (Keuskamp et al. 2013) and to assess the biochemical stability (SUVA 254 (Hansen et al. 2016) and humification index (HIX) (Ohno 2002) optical methods) and source (fluorescence index (FI) (McKnight et al. 2001) of soil DOC.

\section{Materials and methods}

\section{Study sites}

Oak woodland and Sitka spruce plantations represent the two most common British forest types. In the UK, oak covers $16.4 \%$ of land under broadleaves (Brewer 2014a) whilst Sitka spruce covers $50.8 \%$ of land under conifers (Brewer 2014b). Two chronosequences (Benham et al. 2012; Vanguelova et al. 2019) were used: (1) in Alice Holt Forest, Surrey in S.E. England; and, (2) in Kielder Forest, Northumberland in N.E. England to represent a range of tree stand ages and decay classes of deadwood (Table 1). The Alice Holt Forest sites $\left(51^{\circ} 9^{\prime} \mathrm{N}, 0^{\circ} 52^{\prime} \mathrm{W}\right)$ consist of young $(\sim 30$ years old $)$, middle age $(\sim 70$ years old) and old ( $\sim 180$ years old $)$ managed lowland oak forest (mainly Quercus robur, L.) on surface water gleys (stagnosols). The upper soil profile consists of silty clay in the Ah horizon (7 cm deep) over an Eg horizon (8 cm deep). High rates of decomposition in Alice Holt soils mean that there is no distinct $\mathrm{O}$ layer; instead, organic matter is mixed with mineral soil in the upper Ah horizon. The Ah horizon has a bulk density of $704.3 \mathrm{~kg} \mathrm{~m}^{-3}$ and carbon stock of $13.3 \mathrm{t} \mathrm{ha}^{-1}$. The Eg horizon has a bulk density of

Table 1 Site plot information

\begin{tabular}{lllll}
\hline Site & Age group & Age (years) & Rotation & Decay class \\
\hline Alice holt forest & Young & $24-34$ & - & $1-2$ \\
(oak) & Mid & $64-84$ & - & 3 \\
& Old & $184+$ & - & $4-5$ \\
Kielder forest & Young & $12,18,19$ & 2nd & $1-2$ \\
(spruce) & Mid & $20,30,31$ & 2nd & 3 \\
& Old & $46, \sim 60,74$ & 1st, 2nd & $4-5$ \\
\hline
\end{tabular}

Decay class represents the dominant stage of decay found within each age group
$968.2 \mathrm{~kg} \mathrm{~m}^{-3}$ and carbon stock of $22.3 \mathrm{t} \mathrm{ha}^{-1}$. Elevation is $80 \mathrm{~m}$ with monthly average air temperatures ranging between 4.7 and $17.6^{\circ} \mathrm{C}$ with an annual mean of $10.5^{\circ} \mathrm{C}$ and mean annual precipitation of $634 \mathrm{~mm}$. Kielder Forest $\left(55^{\circ} 15^{\prime} \mathrm{N}, 2^{\circ} 23^{\prime} \mathrm{W}\right)$ consists of uniform, managed young ( $10-20$ years old), middle age (20-40 years old) and old (40-60 years old) upland Sitka spruce (Picea sitchensis (Bong.), Carr.) plantations on peaty gley soils and deep peat (stagnohumic gleys/histosols). The upper soil profile is predominantly organic material, with an $\mathrm{O}$ layer ( $2 \mathrm{~cm}$ deep) over the $\mathrm{H}$ peat layer $(17 \mathrm{~cm}$ deep). The $\mathrm{O}$ layer has a bulk density of $86 \mathrm{~kg} \mathrm{~m}^{-3}$ and carbon stock of $22.7 \mathrm{tha}^{-1}$. The $\mathrm{H}$ layer has a bulk density of $157 \mathrm{~kg} \mathrm{~m}^{-3}$ and carbon stock of $114 \mathrm{tha}^{-1}$. Elevation ranges between 240 and $365 \mathrm{~m}$, monthly average air temperatures range between 3 and $14.8{ }^{\circ} \mathrm{C}$ with an annual mean of $8.3^{\circ} \mathrm{C}$, and precipitation of $759 \mathrm{~mm}$. The majority of plots are in their second rotation (i.e. second crop) since afforestation (Table 1). At each site three plots of $10 \mathrm{~m}^{2}$, per chronosequence age group were selected for field measurements and sampling. These age groups contained a range of different sized debris at different stages of decay. The dominant decay stage per age group is shown in Table 1; however, other decay classes were present at each plot. Decay class was visually assessed according to the guidelines by Hunter (1990) as decay classes 1-5, whereby freshly fallen wood with little to no decay is considered class 1 whilst heavily decayed wood is class 5 .

\section{Field sampling}

At each chronosequence plot, five subplots $\left(\sim 1 \times 1 \mathrm{~m}^{2}\right)$ where deadwood was present were randomly selected along with five subplots $\left(\sim 1 \times 1 \mathrm{~m}^{2}\right)$ where no deadwood was present, but only forest leaf litter was. These subplots will be referred to as 'deadwood' and 'leaf litter', respectively. Deadwood diameters at Alice Holt ranged between 5 and $90 \mathrm{~cm}$, with a mean of $10.8 \mathrm{~cm}$. Two samples of large diameter deadwood ( $>30 \mathrm{~cm}$ diameter) were selected due to an absence of smaller debris. Deadwood diameters at Kielder ranged between 5 and $13.7 \mathrm{~cm}$, with a mean of $7 \mathrm{~cm}$. An average mass of $0.1 \mathrm{~kg} \mathrm{~m}^{-2}$ deadwood $\left(\sim 4.5 \mathrm{~m}^{3} \mathrm{ha}^{-1}\right)$ was found at Alice Holt (Hollands et al. 2022) and $\sim 0.3 \mathrm{~kg} \mathrm{~m}^{-2}\left(\sim 10.5 \mathrm{~m}^{3} \mathrm{ha}^{-1}\right)$ at Kielder. After removal of the surface litter layer at both the leaf litter and deadwood plots, a soil sample was taken from the top $10 \mathrm{~cm}$ of soil from all ten subplots. Soil temperature of the soil surface layer from each of the ten subplots was measured with a handheld probe (Delta-T Devices Ltd., UK). This was repeated over two site visits, the first in June-July and the second in September-October 2017. 


\section{Tea bag index}

A tea bag index (Keuskamp et al. 2013), which exploits the differential in decomposition between green tea (Camellia sinensis; fast decomposing) and rooibos tea (Aspalathus linearis; slow decomposing) leaves over ca. 3 months, was used to compare decomposition rate and organic matter stabilization potential of soils under deadwood and neighbouring soils where no deadwood was present. Following the protocol of Keuskamp et al. (2013), pre-weighed pairs of commercially available Lipton green tea and Lipton rooibos tea bags were buried in June and July 2017 and retrieved in September or October after an incubation of 81-85 days. They were buried $8 \mathrm{~cm}$ deep and $15 \mathrm{~cm}$ apart, in the soil layer beneath the deadwood and in leaf litter subplots. Following retrieval, tea bags were oven dried at $60{ }^{\circ} \mathrm{C}$ and external debris removed before weighing. Mass lost between the date of initial burial and retrieval was used to calculate both $\mathrm{k}$, a decomposition rate that measures the turnover time of labile carbon, and S, the stabilisation factor, a measure of the stabilisation potential of organic carbon according to the following equations (Keuskamp et al. 2013).

$W(t)=a_{r} e^{-k t}+\left(1-a_{r}\right)$

$S=1-\left(\frac{a_{g}}{H_{g}}\right)$

where: $W(t)$ is the weight $(g)$ of rooibos tea remaining after incubation time $t(d) ; a_{r}=$ decomposable fraction of rooibos litter $\left(\mathrm{g} \mathrm{g}^{-1}\right)$ as calculated from $\mathrm{S}$ and the hydrolysable fraction of rooibos tea $\left(H_{r}\right) ; k=$ rooibos tea decomposition rate $\left(\mathrm{d}^{-1}\right) . \mathrm{S}=$ stabilization factor (unitless); $a_{g}=$ decomposed fraction of green tea after incubation $\left(\mathrm{g} \mathrm{g}^{-1}\right) ; \mathrm{H}_{\mathrm{g}}$ =hydrolysable fraction of green tea $\left(\mathrm{g} \mathrm{g}^{-1}\right) . H_{g}$ and $H_{r}$ have been previously determined as 0.842 and 0.552 by Keuskamp et al. (2013).

\section{Lab analyses}

Soil samples were kept stored at $4{ }^{\circ} \mathrm{C}$ until analysis. Moisture content of soils were measured gravimetrically as loss of mass on oven heating to $105{ }^{\circ} \mathrm{C}$. Soil organic matter (\%) was measured through mass loss on ignition at $550{ }^{\circ} \mathrm{C}$. Subsamples of soil were oven dried at $105^{\circ} \mathrm{C}$ for $12 \mathrm{~h}$ prior to grinding with a planetary ball mill (Pulverisette 5, Fritsch, Germany). The total $\mathrm{C}$ and $\mathrm{N}$ of ground samples was then measured using a Thermo Flash 2000 Carbon and Nitrogen Analyser.

Water-extractable carbon was determined by mixing $4.5 \mathrm{~g}$ soil in to $45 \mathrm{ml}$ water, at a ratio of 1:10 soil:ultrapure water. These were placed on an end-over-end shaker for $24 \mathrm{~h}$ before $\mathrm{pH}$ was measured and the extracts then centrifuged at $3500 \mathrm{rpm}$ for $15 \mathrm{~min}$. Extracts were then filtered through Whatman GF/A filter papers before centrifuging at $3500 \mathrm{rpm}$ for a further $15 \mathrm{~min}$ and vacuum filtering through $0.45 \mu \mathrm{m}$ cellulose nitrate filter papers. Total organic carbon (TOC; $\mathrm{mg} \mathrm{L}^{-1}$ ) of these filtered solutions was measured using a carbon analyser (Shimadzu TOC-L, Shimadzu Corporation, Japan) as Total Carbon $\left(\mathrm{mg} \mathrm{L}^{-1}\right)$ Inorganic Carbon $\left(\mathrm{mg} \mathrm{L}^{-1}\right)$. As they had been filtered to $0.45 \mu \mathrm{m}$, it is presumed that all TOC measured is DOC. Water-extractable organic carbon (WEOC; $\mathrm{mg} \mathrm{kg}^{-1}$ dry soil) was calculated from the DOC readings to correct for the volume of water used during extraction and dry mass of soils. Quantities of DOC will be referred to as WEOC.

The specific ultraviolet absorbance at $254 \mathrm{~nm}$ $\left(\mathrm{SUVA}_{254}\right)$ can be used as a proxy measurement for the aromatic content of DOC, with higher $\mathrm{SUVA}_{254}$ values indicating a greater aromatic content (Hansen et al. 2016). Absorbance of soil solutions was measuring using spectrophotometer (Jenway 5000, Jenway, UK) at wavelength $254 \mathrm{~nm}$. A baseline of ultrapure water was used and blanks

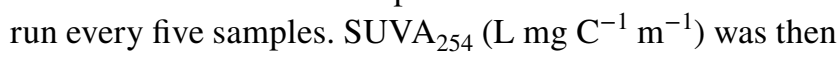
calculated as:

$\mathrm{SUVA}_{254}=\frac{\text { Absorbance }_{254}}{\text { DOC }\left(\mathrm{mg} \mathrm{L}^{-1}\right)} \times 100$

Fluorescence measurements of the soil solutions and enzyme activities were made using a microplate reader (SpectraMax i3x, Molecular Devices, USA). In order to calculate a humification index (HIX), spectra were obtained with an excitation wavelength of $254 \mathrm{~nm}$ over the emissions waveband of 300-480 $\mathrm{nm}$ at increments of $5 \mathrm{~nm}$ (Ohno 2002) and calculated as:

$\mathrm{HIX}=\frac{\sum I_{435 \rightarrow 480}}{\sum I_{300 \rightarrow 345}+\sum I_{435 \rightarrow 480}}$

where $I$ is the detected fluorescence intensity.

A fluorescence index (FI) was calculated using the ratio of wavelengths 470 to $520 \mathrm{~nm}$ at excitation $370 \mathrm{~nm}$ (McKnight et al. 2001).

Enzyme assays to determine potential hydrolytic depolymerase activity rates were selected as follows: carbon cycle $-\beta$-D-cellubiosidase ( $\mathrm{CB}$; cellulose degradation), $\beta$-glucosidase (BG; sugar degradation) and $\beta$-xylosidase (XYL, hemicellulose degradation); carbon and nitrogen cycle-Leucine aminopeptidase (LAP, protein degradation); phosphorus cycle-phosphatase (PHOS, phosphorus mineralisation). Phenol oxidase (POX) activity, an important oxidative enzyme involved in lignin depolymerization was also determined. 
Microplate fluorometric analysis of CB, BG, XYL, LAP and PHOS potential activities in soil slurries were determined using the methods of Bell et al. (2013). Fluorescence was measured at excitation $365 \mathrm{~nm}$ and emission $450 \mathrm{~nm}$ after a two-hour incubation at mean field soil temperature (Table 2). For all enzyme assays, sodium acetate buffer was used and adjusted to the corresponding site $\mathrm{pH}$ (Table 2) using glacial acetic acid.

POX activity was measured following the methods of Allison (2012) using L-dihydroxyphenylalanine (L-DOPA) as a substrate. Optimum incubation times were found after reading plates at absorbance $460 \mathrm{~nm}$ every $30 \mathrm{~min}$ for five hours. Final assay plates were incubated at mean field soil temperature (Table 2 ) for $3.5 \mathrm{~h}$ before measurement.

\section{Deadwood DOC extraction}

In June 2018, the young and old plots at Alice Holt were revisited (Zhao 2018) and samples of deadwood (>10 cm diameter) were collected for the extraction of WEOC. Five samples per plot were selected and cut to $\sim 20 \mathrm{~cm}$ lengths in the field. These were sealed in plastic bags and transported back to the laboratory for storage at $4{ }^{\circ} \mathrm{C}$. Prior to extraction, deadwood samples were cut into $1.5 \mathrm{~cm} \times 1.5 \mathrm{~cm} \times 1.5 \mathrm{~cm}$ cubes of centre wood (i.e. cubes were formed by sawing off the outer wood to leave a cube at the centre) and air dried for 15 days. These were then placed in $50 \mathrm{ml}$ centrifuge tubes and $33.75 \mathrm{ml}$ ultrapure water added. Tubes were shaken on an overhead shaker for $24 \mathrm{~h}$ before centrifuging at $3500 \mathrm{rpm}$ for $15 \mathrm{~min}$. Supernatants were filtered through Whatman GF/A and then through $0.45 \mu \mathrm{m}$ cellulose nitrate filter papers. Filtrates were further diluted as $2 \mathrm{ml}$ sample: $4 \mathrm{ml}$ MilliQ water before analysis on an Analytical Sciences liquid $\mathrm{CN}$ analyser.

\section{Statistical analyses}

Statistical analyses were carried out using R core v 3.5.1 (R Core Team 2017). Data were tested for normality using Shapiro-Wilk test and equality of variances using Levene's test. Data were $\log _{10}$ transformed where equality of variances was not met. The effect of site, stand age and presence of deadwood were analysed using a general linear model. Significant differences were accepted at $p<0.05$. Means are presented with standard errors. Tukey HSD post hoc testing was used to identify where significant differences occurred.

\section{Results}

\section{Effects of deadwood on underlying soil properties}

Soil properties varied significantly between the two sites, with Kielder being cooler, wetter, and more organic and

Table 2 Average surface soil properties $(0-10 \mathrm{~cm}$ depth) from Alice Holt and Kielder Forests \pm 1 standard error of the mean, grouped by stand age and the presence or absence of deadwood

\begin{tabular}{|c|c|c|c|c|c|c|c|c|c|}
\hline & & \multicolumn{4}{|c|}{ Alice holt forest (oak) } & \multicolumn{4}{|c|}{ Kielder forest (spruce) } \\
\hline & & Young & Mid & Old & Mean & Young & Mid & Old & Mean \\
\hline \multirow[t]{4}{*}{ Field soil temperature $\left({ }^{\circ} \mathrm{C}\right)$} & ${ }^{1}$ Leaf litter & $16.9 \pm 0.2$ & $16.6 \pm 0.1$ & $16.5 \pm 0.1$ & $16.6 \pm 0.1^{\mathrm{A}}$ & $10.7 \pm 0.1$ & $10.9 \pm 0.1$ & $10.2 \pm 0.1$ & $10.6 \pm 0.1^{c}$ \\
\hline & ${ }^{1}$ Deadwood & $16.3 \pm 0.1$ & $16.3 \pm 0.1$ & $16.5 \pm 0.1$ & $16.4 \pm 0.1^{\mathrm{B}}$ & $10.7 \pm 0.1$ & $10.8 \pm 0.1$ & $10.2 \pm 0.1$ & $10.6 \pm 0.1^{\mathrm{C}}$ \\
\hline & ${ }^{2}$ Leaf litter & $13.0 \pm 0.1$ & $12.5 \pm 0.1$ & $12.5 \pm 0.1$ & $12.7 \pm 0.0$ & $9.8 \pm 0.0$ & $9.7 \pm 0.1$ & $9.1 \pm 0.1$ & $9.5 \pm 0.0$ \\
\hline & ${ }^{2}$ Deadwood & $13.2 \pm 0.1$ & $12.5 \pm 0.1$ & $12.5 \pm 0.1$ & $12.8 \pm 0.1$ & $9.9 \pm 0.0$ & $9.6 \pm 0.1$ & $9.1 \pm 0.1$ & $9.5 \pm 0.0$ \\
\hline \multirow[t]{2}{*}{$\mathrm{pH}$} & Leaf litter & $4.4 \pm 0.1$ & $4.2 \pm 0.1$ & $4.5 \pm 0.1$ & $4.4 \pm 0.1$ & $3.7 \pm 0.1$ & $3.8 \pm 0.1$ & $4.1 \pm 0.1$ & $3.9 \pm 0.1$ \\
\hline & Deadwood & $4.3 \pm 0.1$ & $4.4 \pm 0.1$ & $4.6 \pm 0.2$ & $4.4 \pm 0.1$ & $3.8 \pm 0.1$ & $3.7 \pm 0.1$ & $4.0 \pm 0.1$ & $3.9 \pm 0.1$ \\
\hline \multirow[t]{2}{*}{ Soil water content $(\%)$} & Leaf litter & $34.6 \pm 1.4$ & $33.2 \pm 1.9$ & $33.6 \pm 2.4$ & $33.8 \pm 1.1$ & $73.0 \pm 3.3$ & $70.8 \pm 1.8$ & $78.4 \pm 0.6$ & $74.0 \pm 1.3$ \\
\hline & Deadwood & $36.5 \pm 1.4$ & $35.6 \pm 3.2$ & $34.3 \pm 2.7$ & $35.4 \pm 1.4$ & $71.6 \pm 1.5$ & $69.2 \pm 2.2$ & $77.1 \pm 1.3$ & $72.6 \pm 1.1$ \\
\hline \multirow{2}{*}{$\begin{array}{l}\text { SOM } \\
(\%)\end{array}$} & Leaf litter & $17.0 \pm 1.3$ & $19.0 \pm 2.7$ & $21.5 \pm 2.6$ & $19.2 \pm 1.3$ & $76.9 \pm 6.4$ & $92.7 \pm 1.6$ & $93.6 \pm 1.2$ & $87.7 \pm 2.5$ \\
\hline & Deadwood & $18.9 \pm 1.0$ & $26.9 \pm 5.0$ & $23.3 \pm 3.0$ & $23.0 \pm 2.0$ & $80.0 \pm 3.7$ & $91.9 \pm 3.4$ & $90.8 \pm 3.2$ & $87.6 \pm 2.1$ \\
\hline \multirow[t]{2}{*}{$\mathrm{C}(\%)$} & Leaf litter & $10.0 \pm 1.2$ & $13.0 \pm 2.7$ & $9.9 \pm 1.4$ & $11.0 \pm 1.1$ & $35.5 \pm 2.9$ & $46.7 \pm 0.3$ & $46.5 \pm 0.8$ & $42.9 \pm 1.3$ \\
\hline & Deadwood & $12.0 \pm 1.3$ & $15.3 \pm 2.3$ & $9.4 \pm 0.9$ & $12.2 \pm 1.0$ & $38.3 \pm 1.7$ & $46.8 \pm 0.5$ & $44.5 \pm 1.7$ & $43.2 \pm 1.0$ \\
\hline \multirow[t]{2}{*}{$\mathrm{N}(\%)$} & Leaf litter & $0.7 \pm 0.1$ & $0.8 \pm 0.1$ & $0.7 \pm 0.1$ & $0.7 \pm 0.1$ & $1.3 \pm 0.1$ & $1.5 \pm 0.0$ & $1.7 \pm 0.1$ & $1.5 \pm 0.1$ \\
\hline & Deadwood & $0.8 \pm 0.1$ & $0.9 \pm 0.1$ & $0.6 \pm 0.0$ & $0.8 \pm 0.1$ & $1.3 \pm 0.1$ & $1.5 \pm 0.1$ & $1.6 \pm 0.1$ & $1.5 \pm 0.0$ \\
\hline \multirow[t]{2}{*}{$\mathrm{C} / \mathrm{N}$} & Leaf litter & $14.5 \pm 0.4$ & $15.1 \pm 0.6$ & $14.2 \pm 0.4$ & $14.6 \pm 0.3$ & $27.8 \pm 1.1$ & $31.4 \pm 1.0$ & $28.4 \pm 1.2$ & $29.2 \pm 0.7$ \\
\hline & Deadwood & $15.3 \pm 0.6$ & $15.7 \pm 0.6$ & $15.4 \pm 0.6$ & $15.5 \pm 0.3$ & $29.0 \pm 1.1$ & $30.3 \pm 0.7$ & $27.6 \pm 1.1$ & $28.9 \pm 0.6$ \\
\hline
\end{tabular}

$N=15$ per group. Field soil temperature and moisture were measured at ${ }^{1}$ time of tea bag burial (June-July) and ${ }^{2}$ time of tea bag retrieval (September-October). Tukey groupings for the effect of interaction between presence of deadwood and site are shown by superscript letters. Where Tukey groupings are not given, there was no significant presence of deadwood * site interaction term 
acidic (Table 2). The larger organic matter content (\%) at Kielder was reflected in the C (\%) measures (43\% and $12 \%$ $\mathrm{C}$ at Kielder and Alice Holt, respectively), and subsequently the surface soil C:N ratio. Presence of deadwood had no effect on soil $\mathrm{pH}(p=0.6)$, gravimetric soil water content $(p=0.721)$, SOM $(p=0.333)$ or soil C:N $(p=0.502)$. Oak subplots with deadwood had slightly higher $\%$ water content but were not found to be statistically significantly different to leaf litter subplots (Table 2), whilst deadwood subplots in the spruce forest had marginally lower water content to the leaf litter subplots.

Stand age affected soil properties across both sites. Soil $\mathrm{pH}$ was significantly higher (0.18-0.41 units) in old stands than the mid-aged and young stands, at both forests $(p<0.001)$. Gravimetric water content was significantly affected by an interaction between site and age $(p=0.013)$ whereby at Kielder, old stands were found to hold significantly more water than the mid-aged stand $(p=0.004)$, with means of $78 \pm 1 \%$ and $70 \pm 1 \%$, respectively. Young stands had a significantly lower organic matter content than old or mid stands $(p<0.001)$ at both forests. Soil C:N was also affected by stand age, with mid-aged stands having a significantly $(p=0.048)$ higher ratio in both forests (Table 2$)$.

\section{Effect of deadwood on surface soil WEOC}

DOC release from deadwood ranged between 0.55 and $15.45 \mathrm{mg}^{-1} \mathrm{~g}^{-1}$ air dried wood, with means of $2.45 \pm 0.49 \mathrm{mg}^{-1} \mathrm{~g}^{-1}$ air dried wood and $3.45 \pm 0.93 \mathrm{mg}^{-1} \mathrm{~g}^{-1}$ air dried wood in the old and young plots at Alice Holt, respectively. Age did not significantly affect the amount of DOC released by deadwood $(p=0.33)$. Concentrations of Water-Extractable Organic Carbon (WEOC) were two to five-fold higher in soils from Kielder Forest than Alice Holt Forest (Fig. 1), averaging 1168 \pm 43 and $353 \pm 45 \mathrm{mg} \mathrm{kg}^{-1}$ dry soil, respectively. There was a significant interaction between site and the presence of deadwood $(p=0.003)$, as soils under deadwood in Alice Holt Forest held $1.45-1.76 \times$ more WEOC than the corresponding leaf litter soils (Tukey HSD $p<0.001$ ). However, there was no effect of the presence of deadwood evident in Kielder Forest plots. Stand age also had no significant effect on WEOC quantity $(p=0.900)$.

A fluorescence index (FI) can be used to infer the source of DOC in the soil solutions. FI values $>1.9$ indicate DOC from a microbial origin, such as lysates and extracellular release from bacteria, whilst values $<1.4$ might indicate an origin from plant material, reflecting contributions from lignin degradation products (McKnight et al. 2001). Soil solutions from Kielder Forest showed a lower FI compared to those from Alice Holt Forest, ranging between 1.07 and 3.31 at Kielder Forest and 1.39 and 4.03 at Alice Holt Forest. Most samples fell within a FI of 1.4-1.9 indicating a mix of origins (Table 3). However, for Alice Holt Forest, soil solutions from the young leaf litter stand and the old stands with deadwood had mean FI values of 2.20 and 2.09, respectively, (Table 3) which indicates a microbial origin only. Soil solutions from under deadwood in the young stands in Kielder Forest had a mean of 1.36 which indicates WEOC originated from plant material only. Because of the differences between stand ages and sites, a significant three-way interaction was found between site, stand age and the presence of deadwood for the fluorescence index $(p=0.013)$. Mean values and the results of Tukey HSD post hoc testing are shown in Table 3.

For soil solutions from Alice Holt Forest the mean humification index (HIX) was higher in soils under deadwood than in leaf litter soils (Table 3), indicating that soil from under deadwood had a greater degree of humification. Significant interaction was found between site and the presence of deadwood $(p=0.015)$ and site and age $(p=0.003)$. The presence of deadwood significantly $(p=0.007)$ increased the HIX value at Alice Holt Forest whilst stand age did not.
Fig. 1 Mean water-extractable organic carbon (WEOC) in surface soil from Alice Holt and Kielder forests with or without deadwood, and in different stand age groups. Error bars are $\pm 1 \mathrm{SE}$ of the mean. $\mathrm{N}=15$ per group. Groups that do not share a letter are significantly different from one another

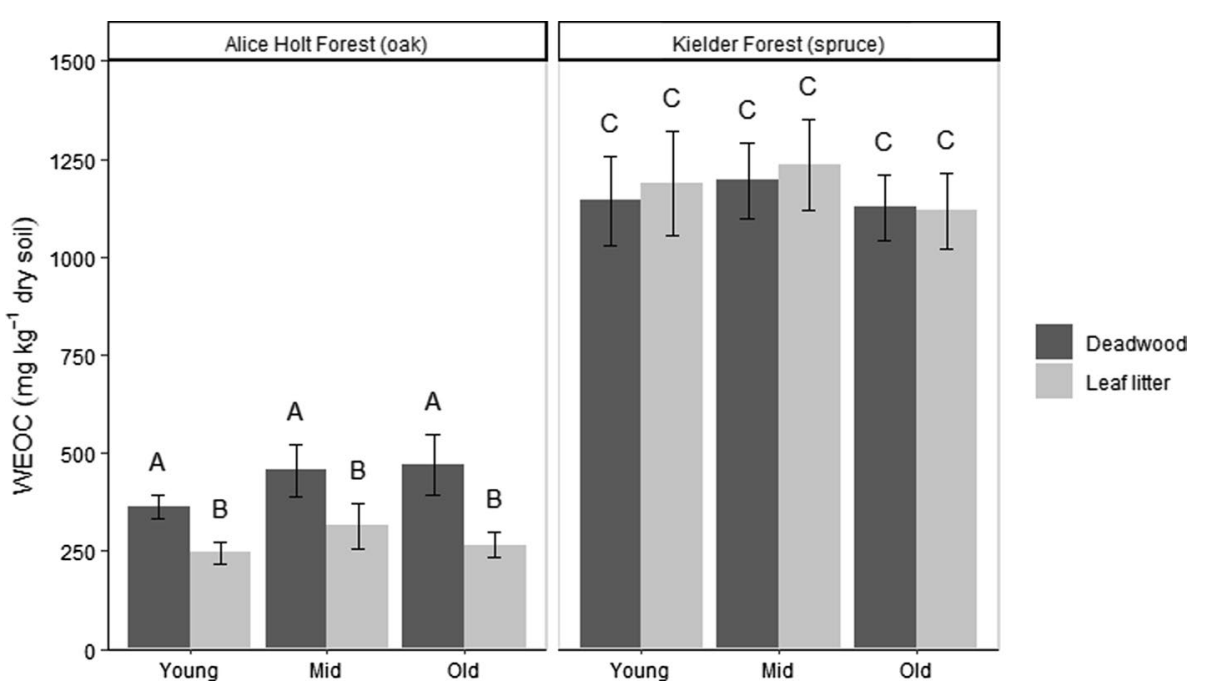


Table 3 Mean optical properties of soil WEOC from Alice Holt and Kielder Forests with or without deadwood, and in different stand age groups

\begin{tabular}{|c|c|c|c|c|c|c|c|c|c|}
\hline & & \multicolumn{4}{|c|}{ Alice Holt Forest (oak) } & \multicolumn{4}{|c|}{ Kielder Forest (spruce) } \\
\hline & & Young & Mid & Old & Mean & Young & Mid & Old & Mean \\
\hline \multirow[t]{2}{*}{ FI } & Leaf litter & $2.20 \pm 0.20^{\mathrm{a}}$ & $1.74 \pm 0.08^{\mathrm{abc}}$ & $1.66 \pm 0.04^{\mathrm{abc}}$ & $1.87 \pm 0.08$ & $1.52 \pm 0.08^{c}$ & $1.53 \pm 0.07^{\mathrm{c}}$ & $1.64 \pm 0.13^{\mathrm{bc}}$ & $1.56 \pm 0.05$ \\
\hline & Deadwood & $1.80 \pm 0.09^{\mathrm{abc}}$ & $1.78 \pm 0.12^{\mathrm{abc}}$ & $2.09 \pm 0.19^{\mathrm{ab}}$ & $1.89 \pm 0.08$ & $1.36 \pm 0.05^{\mathrm{c}}$ & $1.66 \pm 0.14^{\mathrm{abc}}$ & $1.40 \pm 0.04^{\mathrm{c}}$ & $1.48 \pm 0.05$ \\
\hline \multirow[t]{2}{*}{ HIX } & Leaf litter & $0.60 \pm 0.04$ & $0.67 \pm 0.04$ & $0.68 \pm 0.04$ & $0.65 \pm 0.02^{\mathrm{B}}$ & $0.76 \pm 0.03$ & $0.72 \pm 0.04$ & $0.63 \pm 0.05$ & $0.70 \pm 0.02^{\mathrm{AB}}$ \\
\hline & Deadwood & $0.74 \pm 0.03$ & $0.77 \pm 0.04$ & $0.76 \pm 0.04$ & $0.75 \pm 0.02^{\mathrm{A}}$ & $0.74 \pm 0.04$ & $0.74 \pm 0.04$ & $0.60 \pm 0.05$ & $0.70 \pm 0.03^{\mathrm{AB}}$ \\
\hline \multirow{2}{*}{$\begin{array}{l}\operatorname{SUVA}_{254}(\mathrm{~L} \\
\left.\mathrm{mg} \mathrm{C}^{-1} \mathrm{~m}^{-1}\right)\end{array}$} & Leaf litter & $4.62 \pm 0.13$ & $4.90 \pm 0.12$ & $4.73 \pm 0.11$ & $4.75 \pm 0.07^{\mathrm{A}}$ & $4.49 \pm 0.33$ & $3.47 \pm 0.20$ & $3.56 \pm 0.18$ & $3.85 \pm 0.16^{\mathrm{B}}$ \\
\hline & Deadwood & $4.84 \pm 0.06$ & $5.29 \pm 0.24$ & $5.26 \pm 0.28$ & $5.13 \pm 0.13^{\mathrm{A}}$ & $4.12 \pm 0.14$ & $3.48 \pm 0.26$ & $3.54 \pm 0.18$ & $3.72 \pm 0.12^{\mathrm{B}}$ \\
\hline
\end{tabular}

FI-Fluorescence index; HIX-humification index; $\mathrm{SUVA}_{254}$-Specific UV Absorbance at $254 \mathrm{~nm}$. Results of Tukey post hoc testing for the fluorescence index (FI) are shown in lowercase, where a significant three-way interaction occurred. Results of post hoc testing for HIX and SUVA are shown in uppercase. Groups that do not share a letter are significantly different

For Kielder Forest samples, the opposite occurred, whereby presence of deadwood had no significant effect but stand age did (old-mid $p=0.035$, young-mid $p=0.995$, young-old $p=0.006)$, with the old stands having a lower HIX value.

The specific ultraviolet absorbance $\left(\mathrm{SUVA}_{254}\right)$ was significantly larger for soil solutions from Alice Holt Forest than Kielder Forest for all sample groups (Table 3). Significant interactions were found between site and the presence of deadwood $(p=0.032)$ and site and age $(p<0.001)$. Post hoc testing found that the only significant within-site differences occurred at Kielder Forest between the young stand and the mid $(p=0.001)$ and old stands $(p=0.003)$.

\section{Effect of deadwood on tea bag index parameters}

The stabilisation factor of soils ( $\mathrm{S}$ ) and decomposition rate (k) derived from the tea bag index method was up to twofold higher in soils from Kielder Forest than those from Alice Holt Forest, with a significant interaction between site and age $(p<0.04)$, (Fig. 2). The presence of deadwood did not influence either S $(p=0.763)$ or $\mathrm{k}(p=0.720)$. Within Kielder Forest samples, the old stands had a significantly higher $\mathrm{S}$ than the mid stands, with mean values of $0.47 \pm 0.04$ and $0.28 \pm 0.02(p<0.001)$, respectively (Supp. Mat. Table 1). Little variation occurred with the mean decomposition rates derived from the tea bag index (k) between samples (Fig. 2).

It should also be noted that whilst a large number of tea bag pairs were buried ( $n=90$ pairs per site), 21 pairs were discounted due to holes and 26 produced negative $\mathrm{k}$ values, which were discounted from analysis (Table S2 and Discussion in Supplementary Information).

\section{Effect of deadwood on soil enzyme activity potential}

Enzyme activity rates were highly variable between soil samples (large s.e.m, Fig. 3). However, a clear site difference occurred, whereby soil suspensions from Kielder Forest showed significantly higher enzyme activity rates than those from Alice Holt Forest. This site difference ranged from between $1.2 \times$ ( $\beta$-D-cellubiosidase young plots with only leaf litter) to $19.3 \mathrm{x}$ (Leucine aminopeptidase young plots with only leaf litter). Means are presented in Supplementary Information Table S3. However, the presence of deadwood did not appear to stimulate an increase in enzyme activity at either forest, nor
Fig. 2 Average values for the stabilisation factor $(\mathrm{S})$ and decomposition rate $\left(\mathrm{k}, \mathrm{d}^{-1}\right)$ derived from the tea bag index method, in either leaf litter soils or soils under deadwood in stands of different ages at Alice Holt and Kielder Forests. Bars show \pm 1 standard error of the mean

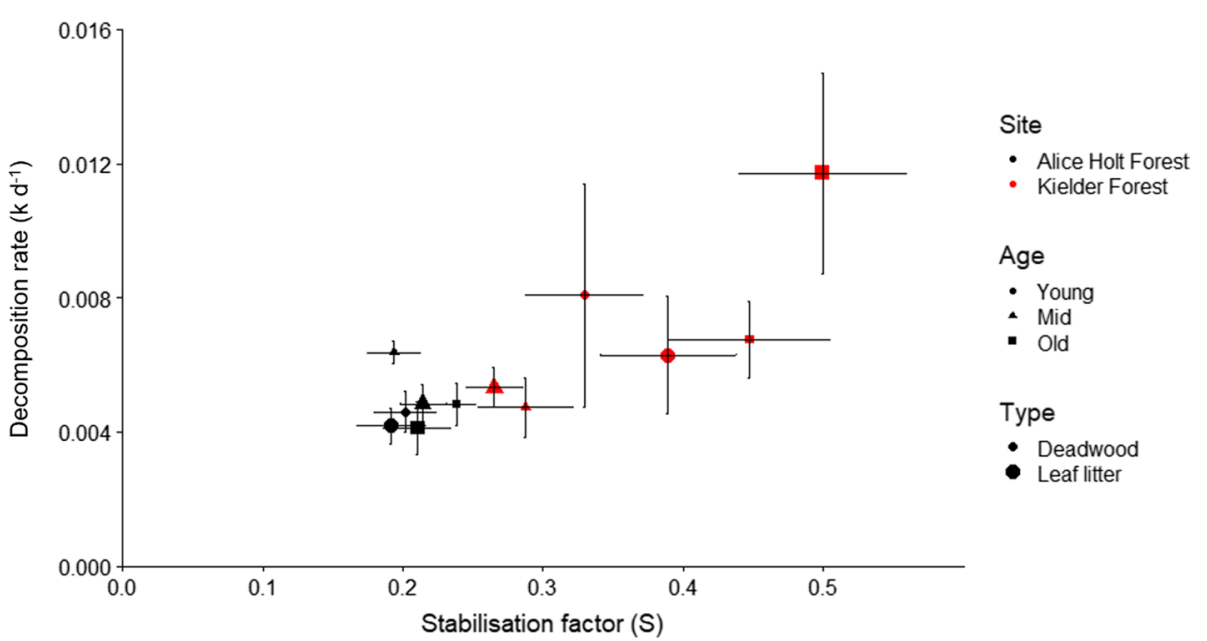




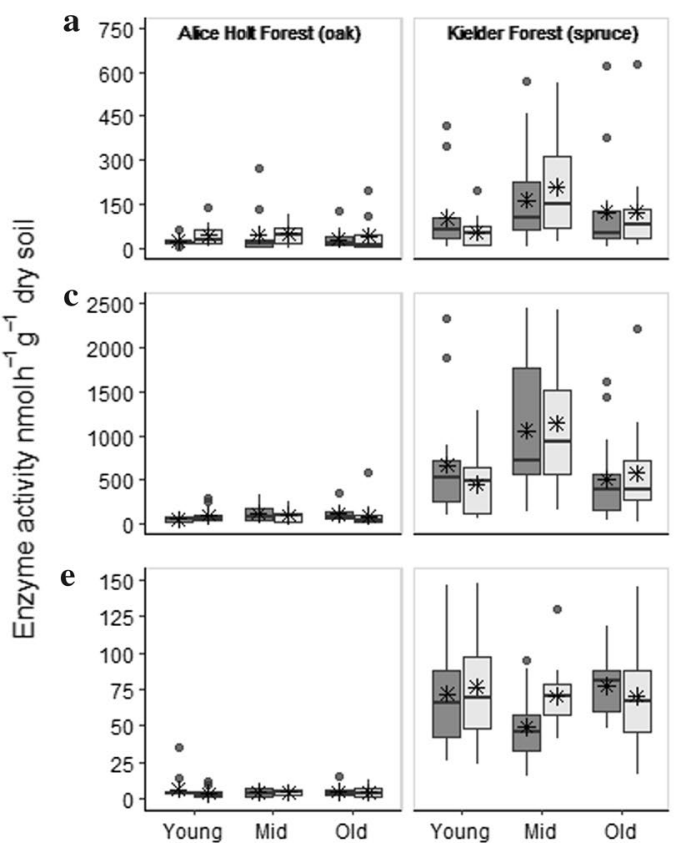

Fig. 3 Potential enzyme activities in soils at Alice Holt and Kielder forests, with and without deadwood, and in different stand age groups: a: $\beta$-D-cellubiosidase, $\mathbf{b}$ : $\beta$-xylosidase, $\mathbf{c}: \beta$-glucosidase, $\mathbf{d}$ : Phosphatase, e: Leucine aminopeptidase, f: Phenol oxidase. Data

in different aged stands. There was no apparent link between DOC origin and enzyme activity rates.

Stand age significantly affected the carbon cycling enzymes $\beta$-glucosidase $(p=0.002)$ and marginally $\beta$-D-cellubiosidase $(p=0.076)$ and $\beta$-xylosidase $(p=0.074)$. A significant interaction was found between site and age for $\beta$-D-cellubiosidase $(p=0.041)$ but not $\beta$-xylosidase $(p=0.093)$. A significant interaction between site, the presence of deadwood and stand age was found for $\beta$-glucosidase $(p=0.011)$. For each of these enzymes, activity rates peaked in the mid-aged stands in both Alice Holt and Kielder Forests. For these three enzymes, at Alice Holt Forest, the average activity rates were between 1.1 and 1.5 times higher in the mid age stands than in young or old stands, whilst at Kielder Forest the rates varied between 1.3 and 2.4 times higher in mid-aged stands than young and old. A significant interaction also occurred between site and stand age for phosphatase activity $(p=0.010)$. Site and stand age effects on enzyme potentials are discussed in the Supplementary Information.

\section{Discussion}

\section{Soil properties in contrasting forest systems}

In order to examine the contribution of deadwood to soil carbon dynamics, we chose to sample soils from stands in a

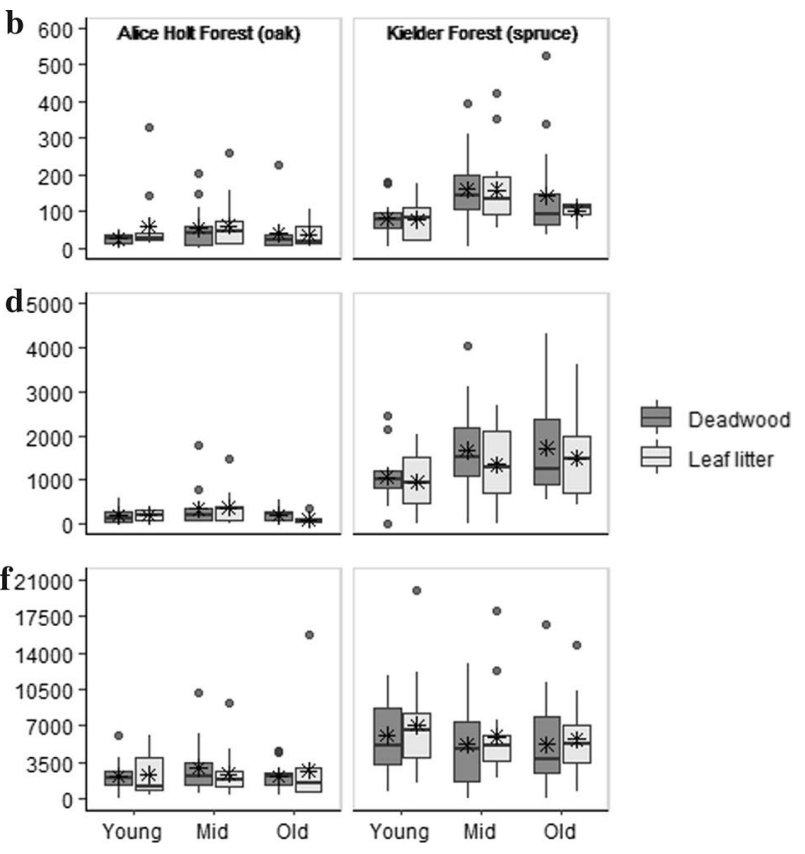

are $*=$ mean $-=$ median, $\bullet=$ outliers defined as outside of the range of plot whiskers, $\pm=$ plot whiskers to show Q1 $-1.5 * \mathrm{IQR}$ or $\mathrm{Q} 3+1.5^{*} \mathrm{IQR}$. Mean values and results of statistical tests can be found in Table 3 of the supplementary material

lowland oak forest (Alice Holt) and an upland Sitka spruce forest (Kielder) as forest sites that contrast but also represent the dominant broadleaf and coniferous forest cover in the UK, covering 16.4\% (Brewer 2014a) and 50.8\% (Brewer 2014b) of forested land, respectively.

There was a clear difference in the soil and WEOC properties between Kielder and Alice Holt Forests, with significant differences occurring between sites for all measures except the HIX. Comparison of soil properties (Table 2) between the two sites reflected the soil classifications of peaty gleys/deep peat and surface water gleys at Kielder and Alice Holt, respectively. The cooler and wetter conditions at Kielder, combined with low $\mathrm{pH}$, inhibit decomposition rates (Hagemann et al. 2010) and favour SOM accumulation (Keith et al. 2009) at this site. Our finding that WEOC concentrations were substantially higher at Kielder (1168 $\mathrm{mg} \mathrm{C} \mathrm{kg}^{-1}$ soil) than Alice Holt (353 $\mathrm{mg} \mathrm{C} \mathrm{kg}^{-1}$ soil) (Fig. 1) most likely reflected the SOM content as a substantial source of soluble carbon (Morison et al. 2012).

\section{Deadwood influence on concentrations of soil water-extractable organic carbon}

It was expected that deadwood would provide a source of DOC into underlying soil. Out of all of the soil properties studied, the clearest effects of deadwood were seen in soil WEOC, albeit in a site-dependent manner. For the surface 
soils under oak at Alice Holt Forest, WEOC concentrations were significantly (between 1.45 and 1.76 times) higher for soils under deadwood when compared to soils without deadwood. However, a deadwood effect on WEOC was not observed in soils from the spruce stands in Kielder Forest. Our finding of greater quantities of WEOC under deadwood at Alice Holt is in accordance with other research that has found that concentrations of soil DOC increase in forests over mineral soils where deadwood is present (Spears and Lajtha 2004; Hafner et al. 2005; Kahl et al. 2012), with increases of up to nine-fold when compared to soils with leaf litter only (Hafner et al. 2005). The organic nature of the peaty-gley Kielder Forest soils may explain why no difference was seen between WEOC in leaf litter soils and soils below deadwood whereas a difference was seen between them in the mineral soils at Alice Holt Forest. In Kielder Forest, where \% organic matter averages $77-94 \%$, the input of DOC by deadwood is likely to be masked by such high levels of existing SOM as a significant source of WEOC. In contrast, at Alice Holt Forest, where \% organic matter averages $17-27 \%$ in topsoil, additional DOC inputs from deadwood may be more easily detectable. In addition, the soil type may have played a role in the retention of deadwood-derived DOC at Alice Holt with lower permeability of the surface water gley leading to reduced potential for leaching losses to lower soil depths. Furthermore, the high silt (particle size $0.063-0.002 \mathrm{~mm}$ ) and clay (particle size $<0.002 \mathrm{~mm}$ ) content $(69 \%$ and $10 \%$ in volume, respectively; Villada 2013) of the sampled A horizon at Alice Holt may have promoted retention of DOC via mineral sorption. The potential for physical protection of DOC through sorption to soil minerals would be, in comparison, limited in the peat soils at Kielder (Schmidt et al. 2011). As a result of the field sampling design, the decay class of deadwood that was sampled within each stand was nested within stand age, reflecting the dominant stage of decay found for each stand age. We initially hypothesized that the effects of deadwood on the soil DOC pool might depend on stand age (decay class) due to differences in DOC fluxes from wood at different stages of decay. Wood in the late stages of decay, i.e. the old stands, is thought to hold a larger fungal and microbial biomass (Kueffer et al. 2008; Baldrian et al. 2016) which has potential to increase rates of decomposition (Peršoh and Borken 2017). However, this was not seen in our results as the deadwood effect on WEOC was of similar magnitude at Alice Holt, irrespective of stand age $(p=0.900)$.

\section{Deadwood influence on soil C cycle processes linked to WEOC concentration and quality}

Microbial priming occurs when fresh inputs of organic matter into the soil, and the subsequent increase in available labile carbon, leads to increased rates of microbial activity stimulating the decomposition of already stored $\mathrm{C}$ in the system (Fontaine et al. 2003; Beverly and Franklin 2015). It was possible that the additional inputs of $\mathrm{C}$ from deadwood might prime depolymerisation of existing SOM pools (Peršoh and Borken, 2017; Minnich et al. 2021), potentially leading to increased WEOC through DOC production. If deadwood DOC-induced microbial priming was occurring in our forest soils, we might expect to find an enhanced decomposition rate, seen in the TBI results, and enhanced potential enzyme activity in the soil under deadwood. In a previous, long-term experiment at Kielder, higher mineralisation and loss of $\mathrm{C}$ was found when brash (branches and litter) was left in situ compared to sites where it was removed, suggesting a likely priming effect (Vanguelova et al. 2010). It is evident at Alice Holt that WEOC concentrations are elevated under deadwood; however, there is no indication through analysis of extracellular enzyme activity or the TBI that this additional soluble $\mathrm{C}$ is priming microbial decomposition or the production of extracellular enzymes involved in decomposition. One possible explanation for the lack of a deadwood effect on decomposition is that the $\mathrm{k}$ parameter in the TBI may not be sensitive to priming effects since $\mathrm{k}$ is estimated from the decomposition of added rooibos tea litter (Keuskamp et al. 2013), which in itself represents an input of fresh organic matter, rather than pre-existing SOM. The lack of an effect of the increased WEOC beneath deadwood on potential enzyme activity might relate to the quality of deadwood DOC inputs, as discussed below.

Optical methods are commonly used to assess the quality of DOC in surface waters, and their potential application to the study of carbon cycling in soils, through characterization of the WEOC, could add to interpretation with respect to the impact of the 'extra' WEOC in soils under the influence of deadwood at Alice Holt. As previously explained (Sect. 2.4 and 3.2), SUVA 254 (Hansen et al. 2016) and a HIX (Ohno 2002) provide a measurement of the aromatic content and degree of humification of WEOC, whereby larger values indicate a larger aromatic content with increased levels of humification related with higher levels of aromatic $\mathrm{C}$ (Zech et al. 1997; Ji et al. 2015). The HIX indicated a greater level of humification and aromaticity, and potentially stability of WEOC, for Alice Holt soils under deadwood $(\mathrm{HIX}=0.75)$ compared to those under leaf litter only (HIX $=0.65)$. Consistent with this deadwood signature in soil WEOC, Bantle et al. (2014) have shown both Quercus sp. and Picea abies -derived DOM to be a more significant source of humified material (HIX $=9.3$ and 7.5, respectively) than throughfall $(\mathrm{HIX}=3.8) . \mathrm{SUVA}_{254}$ also suggested stronger aromaticity for WEOC underneath deadwood although statistical evidence for this was weaker. Amongst the many factors suggested to influence the size and direction of priming effects, the chemical structure of soluble $\mathrm{C}$ inputs has been shown to be important (Di Lonardo et al. 2017). Aromatic compounds 
(e.g. vanillic acid) have been shown to induce the most pronounced priming effects when compared to non-aromatics (e.g. saccharides) on an energy content basis, possibly because they resemble compounds present in more stable SOM (Di Lonardo et al. 2017). In contrast, the aromatic compounds catechin and caffeic acid (a key intermediate in the biosynthesis of lignin) have been shown to have no effect on potential enzyme activity (Zwetsloot et al. 2020). Due to the relatively energy-poor nature of these aromatic monomers, greater concentrations are needed to produce effects on a carbon concentration equivalent basis (Di Lonardo et al. 2017) and therefore it is possible that the aromatic enrichment of the WEOC pool under deadwood at Alice Holt, as suggested by HIX and SUVA $_{254}$, was not of sufficient magnitude to produce detectable effects on corresponding enzyme potentials.

An alternative mechanism to microbial priming by which inputs of soluble organic matter might impact on soil organic matter pools has been suggested. This involves the mobilization and solubilisation of organic $\mathrm{C}$ previously intimately associated with reactive mineral phases through dissolution and metal chelating reactions mediated by inputs of organic compounds that are ligands with metal complexing activities (Keiluweit et al. 2015). If this mechanism was in operation in the Alice Holt soils, the 'extra' WEOC under deadwood would be of both deadwood and soil organic matter origin. The origin of WEOC, as inferred from the FI of $\sim 1.9$ indicated that the WEOC was a mixture of both microbial and plant origin (McKnight et al. 2001) but this did not differ between soils from under deadwood and those under only leaf litter. Whether deadwood-derived DOC contains compounds that are more active as ligands in mobilizing additional soluble $\mathrm{C}$ from mineral associations than those in leaf litter-DOC requires further investigation. At this stage, it is not possible to conclude if elevated WEOC under deadwood at Alice Holt was solely a consequence of stabilized DOC from deadwood or if abiotic priming also contributed.

\section{Conclusions}

The presence of deadwood significantly elevated (by $\sim 1.5$ to $\sim 1.75$ times) the concentrations of soil DOC, analysed as WEOC, in the mineral horizon of a surface water gley chronosequence under lowland broadleaf $(Q$. robur) forest. We believe that this increase in WEOC was, at least in part, due to deadwood acting as a significant input of DOC, released as a result of decomposition processes, to the underlying soil, which was subsequently retained through interactions with the soil mineral horizon. In highly organic soils sampled from an upland Sitka spruce chronosequence, effects of deadwood on WEOC were not detectable. This is potentially because inputs of DOC from deadwood were masked by the already high background of WEOC and/or did not persist in soil due to low potential for mineral sorption. There was no evidence, from TBI decomposition parameters or potential extracellular enzyme data, that deadwood-derived DOC impacted other forest carbon pools via microbial priming effects, possibly due to the aromatic quality of DOC produced. It was not possible to determine whether the increased WEOC under deadwood at the lowland oak site was solely due to retention of deadwood-derived DOC, or, if OC solubilized from existing SOC pools via deadwood DOC-mediated abiotic reactions also contributed. At present, the source and impacts on soil $\mathrm{C}$ cycling of elevated WEOC associated with leaving deadwood in situ requires further characterization. Forest carbon budgets, particularly those for mineral soils, that are only derived from DOC concentrations sampled from under leaf litter may be an underestimation; efforts should be made to include a deadwood component in temporal and spatial monitoring of forest ecosystems.

Supplementary Information The online version contains supplementary material available at https://doi.org/10.1007/s10342-021-01435-3.

Acknowledgements We would like to thank Anne Dudley, Alice Dibley and Ilse Kamerling for their assistance with laboratory analyses and Sue Benham, Ed Eaton and Paul Gough for their assistance with field work. Special thanks also go to Yi Zhao for his work on deadwood DOC extraction, both in the field and the laboratory.

Funding This work was supported by the Natural Environment Research Council (NERC) iCASE studentship with Forest Research (Grant Number: NE/N008529/1).

Data availability Not applicable.

Code availability Not applicable.

\section{Declarations}

Conflict of interest Authors declare that they have no conflict of interest.

Open Access This article is licensed under a Creative Commons Attribution 4.0 International License, which permits use, sharing, adaptation, distribution and reproduction in any medium or format, as long as you give appropriate credit to the original author(s) and the source, provide a link to the Creative Commons licence, and indicate if changes were made. The images or other third party material in this article are included in the article's Creative Commons licence, unless indicated otherwise in a credit line to the material. If material is not included in the article's Creative Commons licence and your intended use is not permitted by statutory regulation or exceeds the permitted use, you will need to obtain permission directly from the copyright holder. To view a copy of this licence, visit http://creativecommons.org/licenses/by/4.0/. 


\section{References}

Allison SD (2012) Allison lab protocol: fluorimetric and oxidative enzyme assays

Baldrian P, Zrustova P, Tlaskal V et al (2016) Fungi associated with decomposing deadwood in a natural beech-dominatedforest. Fungal Ecol 23:109-122. https://doi.org/10.1016/j.funeco. 2016.07.001

Bantle A, Borken W, Ellerbrock RH et al (2014) Quantity and quality of dissolved organic carbon released from coarse woody debris of different tree species in the early phase of decomposition. For Ecol Manage 329:287-294. https://doi.org/10.1016/j.foreco. 2014.06.035

Bell CW, Fricks BE, Rocca JD et al (2013) High-throughput fluorometric measurement of potential soil extracellular enzyme activities. Jove-J vis Exp. https://doi.org/10.3791/50961

Benham SE, Vanguelova EI, Pitman RM (2012) Short and long term changes in carbon, nitrogen and acidity in theforest soils under oak at the Alice Holt Environmental Change Networksite. Sci Total Environ 421:82-93. https://doi.org/10.1016/j.scitotenv.2012. 02.004

Beverly D, Franklin S (2015) Heterotrophic and autotrophic soil respiration under simulated dormancy conditions. Open J for 5:274286. https://doi.org/10.4236/ojf.2015.53024

Brewer A (2014a) 50-year forecast of hardwood timber availability. Edinburgh

Brewer A (2014b) 50-year forecast of softwood timber availability. Edinburgh

Di Lonardo DP, De Boer W, Klein Gunnewiek PJA et al (2017) Priming of soil organic matter: Chemical structure of added compounds is more important than the energy content. Soil Biol Biochem 108:41-54. https://doi.org/10.1016/j.soilbio.2017.01.017

Fontaine S, Mariotti A, Abbadie L (2003) The priming effect of organic matter: a question of microbialcompetition? Soil Biol Biochem 35:837-843. https://doi.org/10.1016/S0038-0717(03)00123-8

Gonzalez-Polo M, Fernandez-Souto A, Austin AT (2013) Coarse woody debris stimulates soil enzymatic activity and litterdecomposition in an old-growth temperate forest of Patagonia, Argentina. Ecosystems 16:1025-1038. https://doi.org/10.1007/ s10021-013-9665-0

Guggenberger G, Kaiser K (2003) Dissolved organic matter in soil: challenging the paradigm of sorptive preservation. Geoderma 113:293-310. https://doi.org/10.1016/S0016-7061(02)00366-X

Hafner SD, Groffman PM (2005) Soil nitrogen cycling under litter and coarse woody debris in a mixedforest in New York State. Soil Biol Biochem 37:2159-2162. https://doi.org/10.1016/j.soilb io.2005.03.006

Hafner SD, Groffman PM, Mitchell MJ (2005) Leaching of dissolved organic carbon, dissolved organic nitrogen, andother solutes from coarse woody debris and litter in a mixed forest inNew York State. Biogeochemistry 74:257-282. https://doi.org/10.1007/ s10533-004-4722-6

Hagemann U, Moroni MT, Gleissner J, Makeschin F (2010) Accumulation and preservation of dead wood upon Burial by bryophytes. Ecosystems 13:600-611. https://doi.org/10.1007/ s10021-010-9343-4

Hansen AM, Kraus TEC, Pellerin BA et al (2016) Optical properties of dissolved organic matter (DOM): Effects ofbiological and photolytic degradation. Limnol Oceanogr 61:1015-1032. https://doi. org/10.1002/lno.10270

Herrmann S, Kahl T, Bauhus J (2015) Decomposition dynamics of coarse woody debris of three important central European tree species. For Ecosyst. https://doi.org/10.1186/s40663-015-0052-5
Hollands C, Shannon VL, Sawicka K et al (2022) Management impacts on the dissolved organic carbon release from deadwood, ground vegetation and the forest floor in a temperate Oak woodland. Sci Total Environ. https://doi.org/10.1016/j.scitotenv.2021.150399

Hunter ML (1990) Wildlife, forests, and forestry: principles of managing forests for biological diversity, 2nd edn. Prentice Hall Career and Technology, Englewood Cliffs, N.J.

Janusz G, Pawlik A, Sulej J et al (2017) Lignin degradation: microorganisms, enzymes involved, genomes analysisand evolution. FEMS Microbiol Rev 41:941-962. https://doi.org/10.1093/femsre/fux049

Ji H, Zhuang S, Zhu Z, Zhong Z (2015) Soil organic carbon pool and its chemical composition in phyllostachypubescens forests at two altitudes in Jian-ou City, China. PLoS ONE. https://doi.org/10. 1371/journal.pone.0146029

Kahl T, Mund M, Bauhus J, Schulze E-D (2012) Dissolved organic carbon from European beech logs: patterns of input to and retention by surface soil. Écoscience 19:364-373

Keiluweit M, Bougoure JJ, Nico PS, Pett-Ridge J, Weber PK, Kleber M (2015) Mineral protection of soil carbon counteracted by root exudates. Nature Climate Change 5(6):588-595. https://doi.org/ $10.1038 /$ nclimate 2580

Keith H, Mackey BG, Lindenmayer DB (2009) Re-evaluation of forest biomass carbon stocks and lessons from theworld's most carbondense forests. Proc Natl Acad Sci U S Am 106:11635-11640. https://doi.org/10.1073/pnas.0901970106

Keuskamp JA, Dingemans BJJ, Lehtinen T et al (2013) Tea Bag Index: a novel approach to collect uniform decomposition dataacross ecosystems. Methods Ecol Evol 4:1070-1075. https://doi.org/10. 1111/2041-210X.12097

Kueffer N, Gillet F, Senn-Irlet B et al (2008) Ecological determinants of fungal diversity on deadwood in Europeanforests. Fungal Divers 30:83-95

Li Z, Dai L-M, Gu H-Y, Lei Z (2007) Review on the decomposition and influence factors of coarse woody debris in forest ecosystem. J for Res 18:48-54. https://doi.org/10.1007/s11676-007-0009-9

Li X, Li M, Pu Y et al (2018) Inhibitory effects of lignin on enzymatic hydrolysis: the role of lignin chemistry and molecular weight. Renew Energy. https://doi.org/10.1016/j.renene.2018.02.079

Lukac M, Godbold DL (2011) Soil ecology in Northern Forests. Cambridge University Press, Cambridge

Matus FJ (2021) Fine silt and clay content is the main factor defining maximal $\mathrm{C}$ and $\mathrm{N}$ accumulations in soils: a meta-analysis. Sci Rep. https://doi.org/10.1038/s41598-021-84821-6

McKnight DM, Boyer EW, Westerhoff PK et al (2001) Spectrofluorometric characterization of dissolved organic matter forindication of precursor organic material and aromaticity. Limnol Oceanogr 46:38-48. https://doi.org/10.4319/lo.2001.46.1.0038

Minnich C, Peršoh D, Poll C, Borken W (2021) Changes in chemical and microbial soil parameters following 8 years of deadwood decay: an experiment with logs of 13 tree species in 30 forests. Ecosystems. https://doi.org/10.1007/s10021-020-00562-z

Morison J, Matthews R, Miller G et al (2012) Understanding the carbon and greenhouse gas balance of forests in Britain. Edinburgh

Ohno T (2002) Fluorescence inner-filtering correction for determining the humificationindex of dissolved organic matter. Environ Sci Technol 36:742-746. https://doi.org/10.1021/es0155276

Olajuyigbe SO, Tobin B, Gardiner P, Nieuwenhuis M (2011) Stocks and decay dynamics of above- and belowground coarse woody debrisin managed Sitka spruce forests in Ireland. For Ecol Manage 262:1109-1118. https://doi.org/10.1016/j.foreco.2011.06.010

Pan Y, Birdsey RA, Fang J et al (2011) A large and persistent carbon sink in the world's forests. Science 80(333):988-993. https://doi. org/10.1126/science. 1201609 
Peršoh D, Borken W (2017) Impact of woody debris of different tree species on the microbial activity and community of an underlying organic horizon. Soil Biol Biochem. https://doi.org/10.1016/j. soilbio.2017.09.017

Piaszczyk W, Blonska E, Lasota J (2019a) Soil biochemical properties and stabilisation of soil organic matter inrelation to deadwood of different species. FEMS Microbiol Ecol. https://doi.org/10.1093/ femsec/fiz011

Piaszczyk W, Lasota J, Błońska E (2019b) Effect of organic matter released from deadwood at different decomposition stages on physical properties of forest soil. Forests 11:24. https://doi.org/ 10.3390/f11010024

R Core Team (2017) R: A language and environment for statistical computing. R Foundation for Statistical Computing, Vienna, Austria. https://R-project.org/

Russell MB, Woodall CW, Fraver S et al (2014) Residence times and decay rates of downed woody Debris biomass/carbon in Eastern US forests. Ecosystems 17:765-777. https://doi.org/10.1007/ s10021-014-9757-5

Schmidt MWI, Torn MS, Abiven S et al (2011) Persistence of soil organic matter as an ecosystem property. Nature 478:49-56. https://doi.org/10.1038/nature10386

Schwarze FWMR, Engels J, Mattheck C (2000) Fungal strategies of wood decay in trees. Springer

Shorohova E, Kapitsa E (2014) Influence of the substrate and ecosystem attributes on the decomposition rates of coarse woody debris in European boreal forests. For Ecol Manage 315:173-184. https://doi.org/10.1016/j.foreco.2013.12.025

Six J, Conant RT, Paul EA, Paustian K (2002) Stabilization mechanisms of soil organic matter: implications forC-saturation of soils. Plant Soil 241:155-176. https://doi.org/10.1023/A:1016125726 789

Spears JDH, Lajtha K (2004) The imprint of coarse woody debris on soil chemistry in the westernOregon Cascades. Biogeochemistry 71:163-175. https://doi.org/10.1007/s10533-004-6395-6

Stutz KP, Kaiser K, Wambsganss J et al (2019) Lignin from whiterotted European beech deadwood and soil functions. Biogeochemistry. https://doi.org/10.1007/s10533-019-00593-2

Tobin B, Black K, McGurdy L, Nieuwenhuis M (2007) Estimates of decay rates of components of coarse woody debris in thinnedSitka spruce forests. Forestry 80:455-469. https://doi.org/10.1093/fores try/cpm024

Vanguelova EI, Pitman R, Luiro J, Helmisaari H-S (2010) Long term effects of whole tree harvesting on soil carbon and nutrient sustainability in the UK. Biogeochemistry 101:43-59. https://doi.org/ 10.1007/s10533-010-9511-9

Vanguelova EI, Nisbet TR, Moffat AJ et al (2013) A new evaluation of carbon stocks in British forest soils. Soil Use Manag 29:169-181. https://doi.org/10.1111/sum.12025
Vanguelova EI, Crow P, Benham S et al (2019) Impact of Sitka spruce (Picea sitchensis (Bong.) Carr.) afforestation onthe carbon stocks of peaty gley soils - a chronosequence study in thenorth of England. Forestry 92:242-252. https://doi.org/10.1093/forestry/ cpz013

Vanguelova EI, Moffat AJ, Morison JIL, Evaluation of volume and carbon storage in deadwood in British Woodland. Under submission

Villada A (2013) Evaluation of tree species and soil type interactions for their potential for long term C sequestration. Dissertation, University of Reading

von Luetzow M, Koegel-Knabner I, Ekschmitt K et al (2006) Stabilization of organic matter in temperate soils: mechanisms and theirrelevance under different soil conditions - a review. Eur J Soil Sci 57:426-445. https://doi.org/10.1111/j.1365-2389.2006.00809.x

Wambsganss J, Stutz KP, Lang F (2017) European beech deadwood can increase soil organic carbon sequestration in forest topsoils. For Ecol Manag. https://doi.org/10.1016/j.foreco.2017.08.053

Weedon JT, Cornwell WK, Cornelissen JHC et al (2009) Global metaanalysis of wood decomposition rates: a role for trait variation among tree species? Ecol Lett 12:45-56. https://doi.org/10.1111/j. 1461-0248.2008.01259.x

Woodall CW, Evans DM, Fraver S et al (2020) Real-time monitoring of deadwood moisture in forests: lessons learned from an intensive case study. Can J for Res. https://doi.org/10.1139/cjfr-2020-0110

Zalamea M, González G, Lodge D (2016) Physical, chemical, and biological properties of soil under decaying wood in a tropical wet forest in Puerto Rico. Forests. https://doi.org/10.3390/f7080168

Zech W, Senesi N, Guggenberger G et al (1997) Factors controlling humification and mineralization of soil organicmatter in the tropics. Geoderma 79:117-161. https://doi.org/10.1016/S00167061(97)00040-2

Zhao Y (2018) Detecting and understanding deadwood effects on soil biogeochemical cycles for sustainable forest management. University of Reading

Zwetsloot MJ, Ucros JM, Wickings K et al (2020) Prevalent rootderived phenolics drive shifts in microbial community composition and prime decomposition in forest soil. Soil Biol Biochem 145:107797. https://doi.org/10.1016/j.soilbio.2020.10

Publisher's Note Springer Nature remains neutral with regard to jurisdictional claims in published maps and institutional affiliations. 